\title{
The First Genetic Linkage Map of Winged Bean [Psophocarpus tetragonolobus (L.) DC.] and QTL Mapping for Flower-, Pod-, and Seed-Related Traits
}

\author{
Sompong Chankaew ${ }^{1} \mathbb{D}$, Sasiprapa Sriwichai ${ }^{1}$, Teppratan Rakvong ${ }^{1}$, Tidarat Monkham ${ }^{1}$, Jirawat Sanitchon ${ }^{1}$, \\ Sithichoke Tangphatsornruang ${ }^{2}{ }^{(0)}$, Wasitthee Kongkachana ${ }^{2}{ }^{(0)}$, Chutima Sonthirod ${ }^{2}$, Wirulda Pootakham ${ }^{2}{ }^{(0)}$, \\ Kitiya Amkul ${ }^{3}$, Anochar Kaewwongwal ${ }^{3}$, Kularb Laosatit ${ }^{3}$ and Prakit Somta ${ }^{3, *(1)}$
}

check for updates

Citation: Chankaew, S.; Sriwichai, S.; Rakvong, T.; Monkham, T.; Sanitchon, J.; Tangphatsornruang, S.;

Kongkachana, W.; Sonthirod, C.;

Pootakham, W.; Amkul, K.; et al. The First Genetic Linkage Map of Winged Bean [Psophocarpus tetragonolobus (L.) DC.] and QTL Mapping for Flower-, Pod-, and Seed-Related Traits. Plants 2022, 11, 500. https://doi.org/ $10.3390 /$ plants 11040500

Academic Editors: Fouad S. Maalouf and Dil Thavarajah

Received: 15 January 2022

Accepted: 10 February 2022

Published: 12 February 2022

Publisher's Note: MDPI stays neutral with regard to jurisdictional claims in published maps and institutional affiliations.

Copyright: (C) 2022 by the authors. Licensee MDPI, Basel, Switzerland. This article is an open access article distributed under the terms and conditions of the Creative Commons Attribution (CC BY) license (https:// creativecommons.org/licenses/by/ $4.0 /)$.
1 Department of Agronomy, Faculty of Agriculture, Khon Kaen University, Khon Kaen 40002, Thailand; somchan@kku.ac.th (S.C.); sasiprapa.sr@kkumail.com (S.S.); teppratan_r@kkumail.com (T.R.); tidamo@kku.ac.th (T.M.); jirawat@kku.ac.th (J.S.)

2 National Omics Center (NOC), National Science and Technology Development Agency, 111 Thailand Science Park, Khlong Nueng, Khlong Luang, Pathum Thani 12120, Thailand; sithichoke.tan@nstda.or.th (S.T.); wasitthee.kon@nstda.or.th (W.K.); chutima.son@nstda.or.th (C.S.); wirulda.poo@nstda.or.th (W.P.)

3 Department of Agronomy, Faculty of Agriculture at Kamphaeng Saen, Kasetsart University, Nakhon Pathom 73140, Thailand; fagrkia@ku.ac.th (K.A.); anochar.au@gmail.com (A.K.); fagrkal@ku.ac.th (K.L.)

* Correspondence: agrpks@ku.ac.th

\begin{abstract}
Winged bean [Psophocarpus tetragonolobus (L.) DC.] $(2 \mathrm{n}=2 \times=18)$ is a tropical legume crop with multipurpose usages. Recently, the winged bean has regained attention from scientists as a food protein source. Currently, there is no breeding program for winged bean cultivars. All winged bean cultivars are landraces or selections from landraces. Molecular markers and genetic linkage maps are pre-requisites for molecular plant breeding. The aim of this study was to develop a high-density linkage map and identify quantitative trait loci (QTLs) for pod and seed-related traits of the winged bean. An $\mathrm{F}_{2}$ population of 86 plants was developed from a cross between winged bean accessions W054 and TPT9 showing contrasting pod length, and pod, flower and seed colors. A genetic linkage map of 1384 single nucleotide polymorphism (SNP) markers generated from restriction site-associated DNA sequencing was constructed. The map resolved nine haploid chromosomes of the winged bean and spanned the cumulative length of $4552.8 \mathrm{cM}$ with the number of SNPs per linkage ranging from 36 to 218 with an average of 153.78. QTL analysis in the $F_{2}$ population revealed 31 QTLs controlling pod length, pod color, pod anthocyanin content, flower color, and seed color. The number of QTLs per trait varied between 1 (seed length) to 7 (banner color). Interestingly, the major QTLs for pod color, anthocyanin content, and calyx color, and for seed color and flower wing color were located at the same position. The high-density linkage map QTLs reported in this study will be useful for molecular breeding of winged beans.
\end{abstract}

Keywords: RAD-seq; SNPs; pod length; seed color; winged bean; anthocyanin

\section{Introduction}

The winged bean [Psophocarpus tetragonolobus (L.) DC.] $(2 \mathrm{n}=2 \times=18)$ is a tropical legume crop belonging to the family Fabaceae and subfamily Papilionoideae [1]. The crop originated in South-East Asia or perhaps Papua New Guinea. It is widely grown in hot humid equatorial countries throughout Southeast Asia and East Africa [2], and is an important leguminous vegetable crop in Thailand, Burma, Laos, Malaysia, Vietnam, Indonesia, Bangladesh, Sri Lanka, Ghana, and Nigeria [2]. Although the young pod of the winged bean is the most popularly consumed part, the rest of the plant parts are also edible when appropriately prepared [3]. Winged bean seeds contain high protein (30-37\%) 
and oil (15-18\%) contents [4,5]. In addition, the winged bean tuber contains roughly $20 \%$ protein and $25-30 \%$ carbohydrates [6]. As a viable candidate for diversifying diets, roasted or boiled tuberous roots are capable of improving the nutritional security of the people in tropical regions [6]. The crop has received scientific praise for its nutritional content, as comprehensively described in 'The winged bean: high-protein crop for the humid tropics' from the National Academy of Science in 1981 [7]. The winged bean is one of the most important legume crops due to its high protein value and multipurpose usage. As a vegetable legume crop, the winged bean holds a unique position in the world of food and agriculture [5]. It has been introduced to more than 80 countries worldwide [8].

The availability and assessment of genetic variability is a prerequisite for crop improvement. The centers of origin and diversity of the winged bean are not yet known. In addition, the ancestors of the winged bean are still not known and may be extinct [9]. However, winged beans from Papua New Guinea and Indonesia have been reported to be diverse, while increasing numbers of winged bean landraces have recently been discovered in Thailand $[2,10]$. Studies of genetic diversity have demonstrated that the winged bean has moderate genetic variation $[5,8,10-12]$.

All winged bean cultivars planted today are indigenous or local cultivars. The demand for winged bean production is increasing, due to its security as a staple food source and multipurpose usage [13]. Therefore, cultivars possessing higher yields with improved traits are desirable. However, knowledge on the genetics and breeding of the winged bean is very limited. Most previous studies in this crop focused on production systems and variation in morphological traits $[6,14,15]$.

Very limited information on the genetics and genomics of the winged bean has been reported. The genome size of winged beans is large $(2 n=2 \times=18 ; 1.22 \mathrm{Gbp} / \mathrm{C})$ [11], and until now a genetic linkage map of the winged bean is not available. All previous studies of molecular genetics and genomics of the winged bean have been related to genetic diversity using first and/or second-generation DNA markers (RAPD and ISSR markers [5], ISSR [8], and SSR [10]). As a result, there exists no study on the molecular breeding of the winged bean, due to a lack of genomic tools.

A genetic linkage map is an indispensable tool for molecular breeding of crops as it is necessary identify the quantitative trait loci (QTLs) or genes controlling traits in breeding programs which will be ultimately useful for marker-assisted selection. To construct a genetic linkage map, DNA markers must be developed. Although some SSR and SNP markers have been developed for the winged been [11,12], not many of them have been validated for use in molecular analysis. In addition, the analysis of SSR and SNP markers in winged bean is expensive, laborious, and difficult because of its large genome size. Recently, next-generation sequencing (NGS) technologies have accelerated whole-genome sequencing and genotyping [16]. Whole genomes of numerous legume species, including mungbean (Vigna radiata) [17], cowpea (V. unguiculata [L.] Walp.) [18], beach pea (V. marina) [19], adzuki bean (V. angularis) [20], pea (Pisum sativum L.) [21], pigeonpea (Cajanus cajan) [22], chickpea (Cicer arietinum) [23], peanut (Arachis ipaensis) [24], and soybean (Glycine max) [25] have been sequenced. Genotyping using high-throughput NGS technologies reduces the complexity of genome analysis and allows the development of numerous SNP markers for any species of interest [26]. Restriction-site associated DNA sequencing (RAD-seq), including double digested RAD-seq (ddRAD-seq), is a preferable NGS-based technology for high-throughput genotyping [16,27]. The RAD-seq method, first described by Baird et al. [28], can be employed without a reference genome, and a reference-guided RAD-seq approach can improve the accuracy of SNP detection.

In this study, we aimed to develop the first genetic linkage map and identify QTL controlling flower-, pod- and seed-related traits in the winged bean. The map was constructed using SNP markers generated by the RAD-seq method. The genetic linkage map and the QTL information generated from this study will facilitate the molecular breeding of winged beans in future studies. 


\section{Results}

\subsection{Variation in Pod Anthocyanin Content, Pod Length, Seed Length, and Seed Width}

The parents, TPT9 and W054, of the $\mathrm{F}_{2}$ mapping population used in this study were clearly different in pod anthocyanin content (pod color) and pod length, but only slightly different in seed size (length and width). Pod anthocyanin content of W054 was 17 times higher than that of TPT9. The value of the content was 40.93 and $2.40 \mathrm{mg} / 100 \mathrm{~g}$ for the former and the latter, respectively (Figure 1A). The values of the pod anthocyanin contents in the $\mathrm{F}_{2}$ population ranged from 1.91 to $34.28 \mathrm{mg} / 100 \mathrm{~g}$, with an average of $9.08 \mathrm{mg} / 100 \mathrm{~g}$. Pod length of the W054 and TPT9 was 24.29 and $15.06 \mathrm{~cm}$, respectively. The pod length in the $\mathrm{F}_{2}$ population varied from 14.25 to $26.50 \mathrm{~cm}$ with an average of $19.25 \mathrm{~cm}$ (Figure 1B). TPT9 and W054 produced seed length of 8.21 and $9.22 \mathrm{~mm}$, respectively (Figure 1C). Seed length in the $F_{2}$ population varied between 7.67 and $10.70 \mathrm{~mm}$, with an average of $9.43 \mathrm{~mm}$. Seed width of TPT9 was $7.89 \mathrm{~mm}$, while that of W054 was $7.13 \mathrm{~mm}$. However, the seed width in the $F_{2}$ population ranged from 5.82 to $9.10 \mathrm{~mm}$, with an average of $7.76 \mathrm{~mm}$ (Figure 1D). Variation of pod anthocyanin content, pod length, seed length, and seed width in the $\mathrm{F}_{2}$ population was continuous and normally distributed (Figure 1) (Durbin-Watson statistic test with $p$-values of $0.7053,0.2435,0.9836$, and 0.1926 , respectively-data not shown), suggesting that they are quantitative traits and possibly controlled by polygenes.

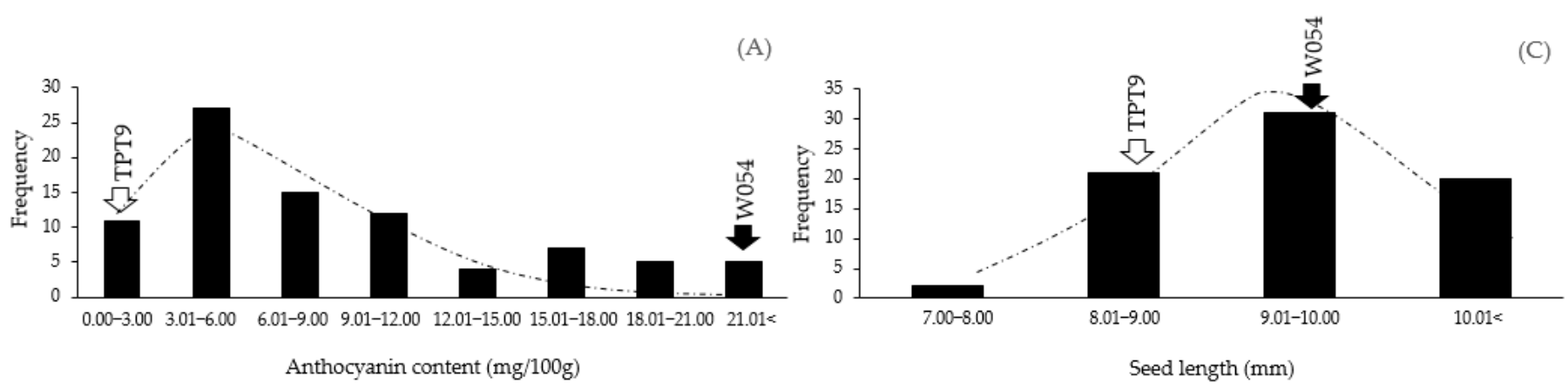

B)

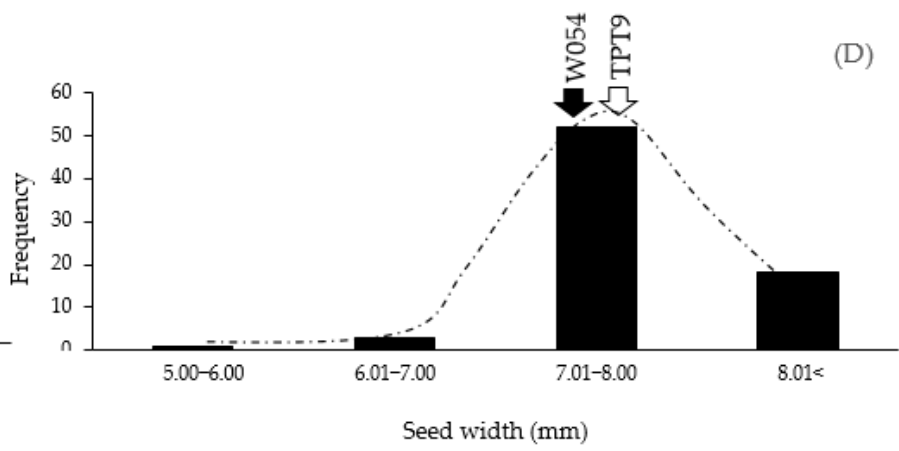

Figure 1. Frequency distribution of pod anthocyanin content (A), pod length (B), seed length (C), and seed width $(\mathbf{D})$ of the winged bean $\mathrm{F}_{2}$ population derived from the cross W054 $\times$ TPT9.

\subsection{Variation in Organ Coloration}

TPT9 and W054 were contrastive in pod, seed, and flower (calyx, wing, and banner) color (Figure 2). All of these traits except seed coat color showed high variation in the $\mathrm{F}_{2}$ population. For example, pod colors of TPT9 and W054 were blue and purple, respectively, while pod colors in the $\mathrm{F}_{2}$ population were green, green with purple spots, green with a purple spot at center, purple wing, purple center, light purple, purple, and dark purple (Figure 2A). Interestingly, wing and banner colors showed transgressive segregation; some colors not existing in both parents. Classes and patterns of segregation of wing color and banner color in the $F_{2}$ population were nearly the same (Figure 2D,E), suggesting that colorations of these two organs were controlled by the same genes or tightly linked genes. 
Nonetheless, these results suggest that coloration of pod, seed, and flower (calyx, wing, and banner) color is controlled by two or more genes in which some of the genes have pleotropic effect or are linked.
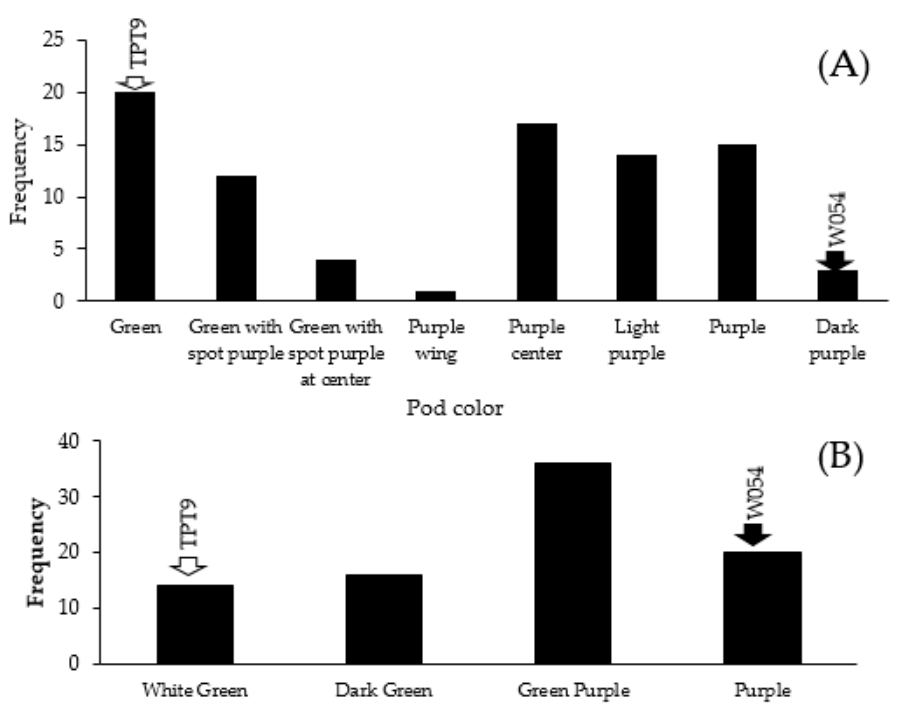

(B)

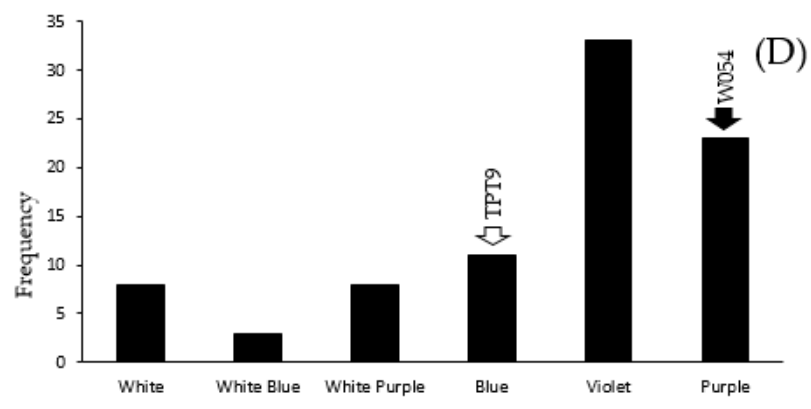

Wing color

(E)

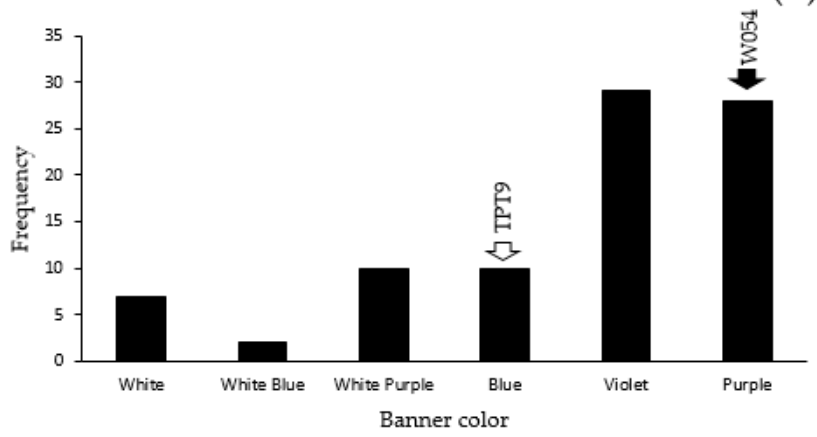

Figure 2. Frequency distribution of coloration of pod (A), calyx (B), seed (C), wing (D), and banner (E) in the winged bean $\mathrm{F}_{2}$ population derived from the cross W054 $\times$ TPT9.

Results of Pearson's correlation coefficient analysis of the nine flower-, pod-, and seedrelated traits in the $\mathrm{F}_{2}$ population are presented in Table 1 . The anthocyanin content was significantly correlated with pod color (0.748) and calyx color (0.706). Pod color and flower color were also significantly correlated, as were pod color and calyx color (0.812), calyx color and wing color (0.543), calyx color and banner color (0.523). The highest correlation was found between the wing color and banner color (0.978) (Table 1). Moreover, seed color was also significantly correlated with pod color (0.547) and calyx color (0.595) (Table 1). The significant correlation among flower, pod, and seed colors indicates, again, that colorations of these organs are controlled by the same or closely linked gene(s).

Table 1. Correlation between pod anthocyanin content, pod length, seed length, seed width; and pod, seed, calyx, wing, and banner colors of the winged bean $\mathrm{F}_{2}$ population derived from cross W054 × TPT9.

\begin{tabular}{ccccccccc}
\hline Traits & AnthoCy & PDL & PDC & CalyxC & WingC & BannerC & SeedL & SeedW \\
\hline PDL & $0.248^{*}$ & & & & & & & \\
PDC & $0.748^{* *}$ & $0.329^{* *}$ & & & & & \\
CalyxC & $0.706^{* *}$ & $0.262^{*}$ & $0.812^{* *}$ & & & & \\
WingC & $0.431^{* *}$ & 0.091 & $0.421^{* *}$ & $0.543^{* *}$ & & & \\
BannerC & $0.419^{* *}$ & 0.081 & $0.405^{* *}$ & $0.523^{* *}$ & $0.978^{* *}$ & & & \\
\hline
\end{tabular}


Table 1. Cont.

\begin{tabular}{ccccccccc}
\hline Traits & AnthoCy & PDL & PDC & CalyxC & WingC & BannerC & SeedL & SeedW \\
\hline SeedL & 0.158 & 0.151 & 0.110 & 0.095 & 0.082 & 0.114 & & $0.500^{* *}$ \\
SeedW & -0.034 & -0.008 & 0.010 & -0.027 & -0.110 & -0.096 & -0.018 & -0.197 \\
SeedC & $0.381^{* *}$ & $0.239^{*}$ & $0.547^{* *}$ & $0.595^{* *}$ & $0.400^{* *}$ & $0.378^{* *}$ & -0.07 \\
\hline
\end{tabular}

AnthoCy = pod anthocyanin content, $\mathrm{PDL}=$ pod length, $\mathrm{SDL}=$ seed length, $\mathrm{SDW}=$ seed width, $\mathrm{PDC}=$ pod color, $\mathrm{SDC}=$ seed coat color, CalyxC $=$ calyx color, $\mathrm{WingC}=$ wing color, and BannerC $=$ banner color. ${ }^{*}$ Significant at 0.05 probability. ${ }^{* *}$ Significant at 0.01 probability.

\subsection{Construction of the Winged Bean Genetic Linkage Map}

\subsubsection{RAD-Seq Library Construction, Sequencing, and SNP Calling}

In this study, a RAD-seq library was constructed using the MGIEasy RAD library kit on $86 \mathrm{~F}_{2}$ populations and their parents and sequenced on MGISEQ-2000RS using PE (150 bp) chemistry. A total of $261.9 \mathrm{Gbp}$ reads were obtained (an average of $3.13 \mathrm{Gbp}$ per sample); each read contained $150 \mathrm{bp}(\times 2)$. Among these data, $85.57 \%$ of bases were high quality (>Q30), and the average guanine-cytosine (GC) content was $38.76 \%$. The sequencing depth corresponded to 21.61-fold in TPT9, 14.71-fold in W054, and 25.62-fold in the $86 \mathrm{~F}_{2}$ progenies (Table S1). A total of 23,576 polymorphic SNP markers were identified from the two parents. There were four types of polymorphic SNP markers: aa $\times b b, h k \times h k$, $\operatorname{lm} \times 1 \mathrm{l}$, and $\mathrm{nn} \times \mathrm{np}$. Since both of the parents were highly inbred, only the aa $\times$ bb genotypes showing homozygous and polymorphic between the parents were used in further analysis.

\subsubsection{Construction of the Winged Bean Genetic Linkage Map}

While a total of 193,735 SNPs were identified, only the aa $\times$ bb marker could be used in the linkage analysis. After SNPs with a minor allele frequency $>0.1$, depth coverage between $10 \times-200 \times$, fewer than $10 \%$ missing data, non-segregation distortion, and non-redundant genotypes were filtered, 1384 SNP markers remained and were constructed into a genetic linkage map. The map of the $\mathrm{F}_{2}$ population contained nine linkage groups (LGs) (Figure S1) and spanned a cumulative distance of $4552.8 \mathrm{cM}$ (Table 2). The length of each LG ranged from $164.96 \mathrm{cM}$ (LG6) to $755.74 \mathrm{cM}$ (LG2), with an average of $505.87 \mathrm{cM}$. The number of SNP markers mapped in each linkage group varied from 36 markers on LG06 to 218 markers on LG02, with an average of 153.78 SNPs per LG (Table 2). The average distance between adjacent markers across the nine LGs was $3.38 \mathrm{cM}$ (Table 2).

Table 2. Characteristics of an SNP-based linkage map constructed for winged bean $\mathrm{F}_{2}$ population of 86 individuals derived from the cross W054 × TPT9.

\begin{tabular}{ccccc}
\hline Linkage Group & $\begin{array}{c}\text { Number of SNP } \\
\text { Markers }\end{array}$ & Length (cM) & $\begin{array}{c}\text { Average Marker } \\
\text { Interval (cM) }\end{array}$ & $\begin{array}{c}\text { Maximum } \\
\text { Interval (cM) }\end{array}$ \\
\hline 1 & 208 & 707.12 & 3.40 & 11.09 \\
2 & 218 & 755.74 & 3.47 & 11.98 \\
3 & 186 & 604.61 & 3.25 & 13.37 \\
4 & 170 & 507.73 & 2.98 & 11.53 \\
5 & 96 & 293.99 & 3.06 & 9.55 \\
6 & 36 & 164.96 & 4.58 & 16.44 \\
7 & 176 & 560.28 & 3.18 & 10.67 \\
8 & 180 & 587.78 & 3.27 & 15.90 \\
9 & 114 & 370.59 & 3.25 & - \\
\hline Average & 153.78 & 505.87 & 3.38 & - \\
\hline Total & 1384 & 4552.8 & - & \\
\hline
\end{tabular}

\subsection{QTL Analysis for Flower-, Pod-, and Seed-Related Traits}

Two methods, ICIM implemented in software QTL IciMapping 4.1 and MQM implemented in MapQTL 5.0, were used for QTL analysis. For ICIM for which a LOD score of 3.0 
was set as significant threshold for QTL analysis, a total of 31 significant QTLs on seven LGs were identified for the nine traits related to flower, pod, and seed. No QTL was detected on LG6 or LG9 (Table 3 and Figure 3). The additive effect for almost all QTLs was positive, indicating that the allele(s) from W054 increase values of these traits (Table 3). In the case of MQM, for which a significant LOD threshold was computed by a 1000-permutation test, only 8 significant QTLs were detected and no QTL was found for seed length and seed width (Table 4 and Figure 4). The QTLs were on LG1, LG2 and LG3, and most of them are on the LG1. The major QTL of each trait was always detected by both methods. Nonetheless, details of the QTLs detected by ICIM are described.

Table 3. Details of the QTLs detected for pod flower-, pod- and seed-related traits in an $\mathrm{F}_{2}$ population of winged bean derived from the cross W054 $\times$ TPT9 by inclusive composite interval mapping method.

\begin{tabular}{|c|c|c|c|c|c|c|c|c|}
\hline Traits & QTLs & LGs & Positions & Marker Interval & LOD Score & PVE (\%) & Add & Dom \\
\hline \multirow[t]{2}{*}{ Anthocyanin content } & qAntho1.1 & 1 & 599.2 & 90362_173-86339_105 & 6.41 & 28.92 & 4.41 & 1.47 \\
\hline & qAntho5.1 & 5 & 137.4 & 129210_17-74111_70 & 3.29 & 11.61 & -2.16 & -2.81 \\
\hline \multirow[t]{4}{*}{ Pod length } & $q P p l 1.1$ & 1 & 601.3 & 86339_105-88581_215 & 3.54 & 11.08 & 0.86 & 1.18 \\
\hline & $q P d l 1.1$ & 1 & 609.8 & 88581_7-113679_228 & 3.03 & 9.49 & 0.88 & 1.04 \\
\hline & $q P d l 2.1$ & 2 & 236.6 & 65543_37-65543_66 & 4.79 & 16.17 & 0.44 & 1.79 \\
\hline & $q P d l 8.1$ & 8 & 503.0 & 758788_184-45825_50 & 3.39 & 11.22 & 1.39 & 0.01 \\
\hline \multirow[t]{3}{*}{ Pod color } & $q P d c 1.1$ & 1 & 599.4 & 86339_105-88581_215 & 16.82 & 49.15 & 2.22 & 0.15 \\
\hline & $q P d c 1.2$ & 1 & 643.9 & 50448_148-73516_244 & 4.84 & 10.35 & 0.06 & 1.56 \\
\hline & $q P d c 7.1$ & 7 & 560.2 & 6763_192-141967_88 & 4.81 & 9.69 & 1.02 & -0.47 \\
\hline \multirow[t]{3}{*}{ Calyx color } & $q C l x c 1.1$ & 1 & 599.4 & 86339_105-88581_215 & 12.26 & 38.28 & 0.76 & 0.05 \\
\hline & $q C l x c 1.2$ & 1 & 664.9 & 5563_75-37621_162 & 5.84 & 15.01 & 0.08 & 0.74 \\
\hline & $q C l x_{c} 7.1$ & 7 & 543.1 & 1977_174-6763_192 & 5.12 & 12.67 & 0.44 & -0.23 \\
\hline \multirow[t]{5}{*}{ Wing color } & qWingc1.1 & 1 & 569.0 & 49233_195-144410_63 & 6.01 & 16.33 & 0.76 & 0.03 \\
\hline & qWingc1.2 & 1 & 649.8 & 73516_104-64897_31 & 3.67 & 9.72 & -0.05 & 0.85 \\
\hline & qWingc3.1 & 3 & 340.7 & 59095_37-59095_183 & 6.72 & 18.61 & -0.93 & 0.05 \\
\hline & qWingc7.1 & 7 & 0.0 & 92184_83-54946_220 & 3.17 & 7.77 & -0.48 & 0.29 \\
\hline & qWingc7.1 & 7 & 435.3 & 79824_126-57556_229 & 4.85 & 12.77 & 0.79 & -0.02 \\
\hline \multirow[t]{7}{*}{ Banner color } & qBannerc1.1 & 1 & 670.1 & $\begin{array}{l}\text { 37621_240- } \\
\text { 101902_163 }\end{array}$ & 3.65 & 6.45 & 0.32 & 0.66 \\
\hline & qBannerc1.2 & 1 & 706.5 & 71361_136-71361_18 & 3.09 & 5.54 & 0.48 & 0.52 \\
\hline & qBannerc3.1 & 3 & 340.1 & 120628_171-59095_37 & 7.34 & 17.75 & -1.02 & 0.10 \\
\hline & qBannerc3.2 & 3 & 345.1 & $\begin{array}{l}\text { 59095_229- } \\
\text { 542971_120 }\end{array}$ & 6.12 & 14.84 & 0.02 & 1.21 \\
\hline & qBannerc4.1 & 4 & 283.3 & $\begin{array}{l}\text { 29428_113- } \\
\text { 114955_133 }\end{array}$ & 3.17 & 6.66 & -0.18 & 0.79 \\
\hline & qBannerc5.1 & 5 & 81.4 & 42289_151-31093_166 & 4.46 & 9.57 & -0.24 & 0.99 \\
\hline & qBannerc7.1 & 7 & 435.3 & 79824_126-57556_229 & 5.27 & 11.51 & 0.85 & 0.32 \\
\hline Seed length & $q S d l 7.1$ & 7 & 414.7 & 143811_217-2570_116 & 3.21 & 18.83 & 0.48 & 0.12 \\
\hline \multirow[t]{4}{*}{ Seed width } & $q S d w 1.1$ & 1 & 294.8 & 79225_198-130456_96 & 3.70 & 14.43 & 0.27 & 0.29 \\
\hline & $q S d w 1.2$ & 1 & 347.9 & 88187__3-100448_14 & 3.19 & 11.47 & 0.23 & 0.29 \\
\hline & $q S d w 1.3$ & 1 & 367.2 & 46319_242-77017_78 & 3.47 & 12.41 & 0.20 & 0.30 \\
\hline & $q S d w 2.1$ & 2 & 134.6 & 10683_187-3208_238 & 4.16 & 18.52 & -0.09 & 0.51 \\
\hline \multirow[t]{2}{*}{ Seed color } & $q S d c 1.1$ & 1 & 660.9 & 64897_73-73327_179 & 22.74 & 73.33 & 0.78 & 0.89 \\
\hline & $q S d c 3.1$ & 3 & 277.3 & 74742_203-41532_216 & 3.27 & 5.45 & -0.30 & 0.01 \\
\hline
\end{tabular}



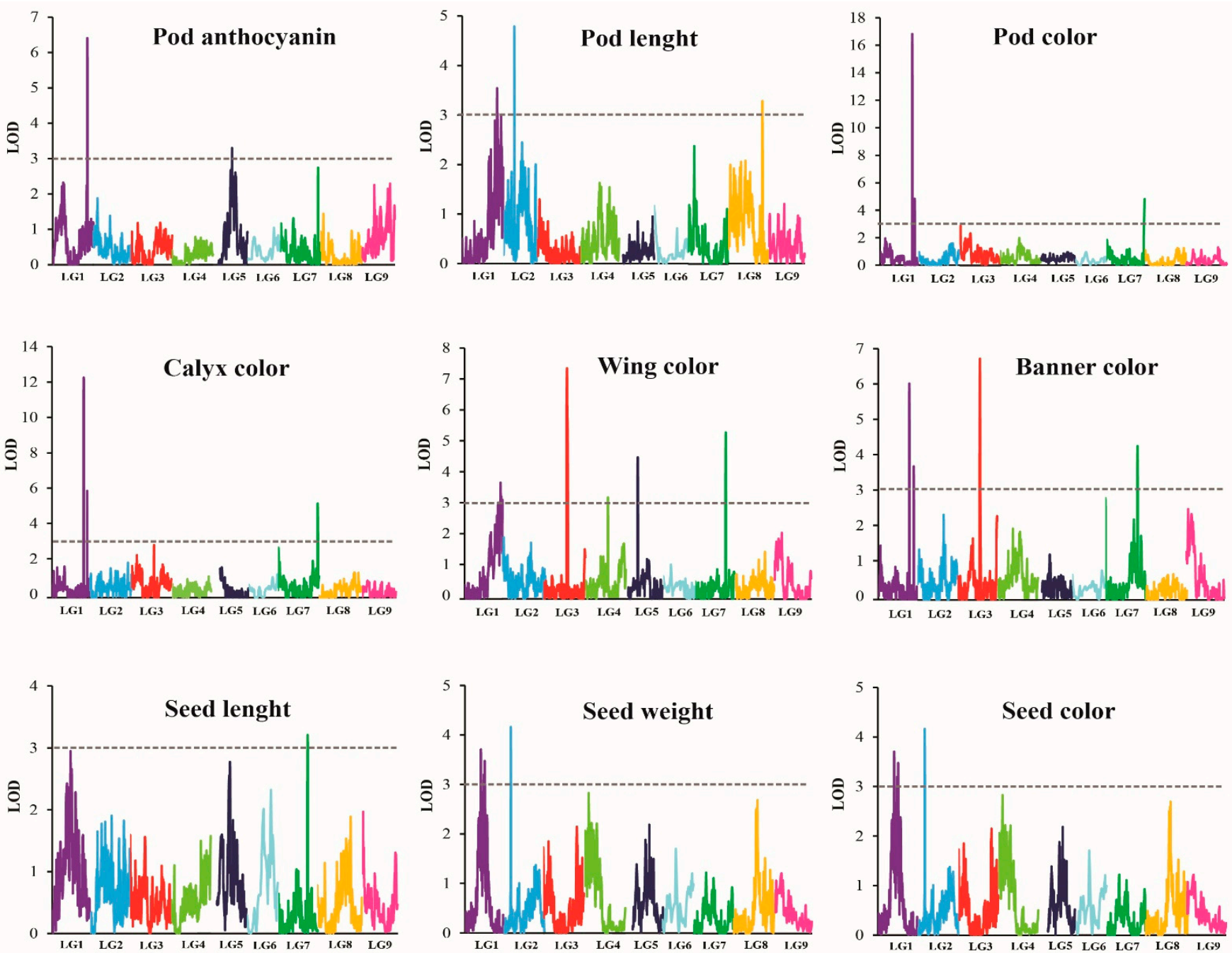

Figure 3. LOD (Logarithm of odds) graphs of quantitative trait loci for flower-, pod-, and seedrelated traits detected by inclusive composite interval mapping (ICIM) method in the winged bean $\mathrm{F}_{2}$ population developed from the cross W054 $\times$ TPT9. The $x$-axis indicates the linkage groups, whereas the $y$-axis indicates the logarithm of odds (LOD) scores. The dash line horizontal to the $y$-axis indicates the LOD significance threshold.

Table 4. Details of the QTLs detected for pod flower-, pod- and seed-related traits in an $\mathrm{F}_{2}$ population of winged bean derived from the cross W054 × TPT9 by multiple QTL mapping method.

\begin{tabular}{|c|c|c|c|c|c|c|c|c|}
\hline Traits & QTLs & LGs & Positions & Marker Interval & LOD Score & PVE (\%) & Add & Dom \\
\hline Anthocyanin & qAntho1.1 & 1 & 566.5 & 59413_160-49233_195 & 6.57 & 29.60 & 4.57 & 2.15 \\
\hline Pod length & $q P p l 2.1$ & 2 & 235.5 & 69533_212-65543_37 & 5.18 & 24.20 & 0.51 & 2.03 \\
\hline Pod color & $q P d c 1.1$ & 1 & 599.4 & 86339_105-88581_215 & 14.26 & 53.40 & 2.15 & 1.39 \\
\hline Calyx color & $q C l x c 1.1$ & 1 & 673.03 & 37621_240-101902_163 & 12.78 & 49.60 & 0.82 & 0.83 \\
\hline \multirow[t]{2}{*}{ Wing color } & qWingc1.1 & 1 & 664.83 & 73327_66-5563_75 & 3.94 & 19.00 & 0.72 & 0.68 \\
\hline & qWingc3.1 & 3 & 372.46 & 52207_209-15865_163 & 5.44 & 25.30 & -0.76 & 0.96 \\
\hline Banner color & qBannerc3.1 & 3 & 338.69 & 120628_171-59095_37 & 6.69 & 30.10 & -0.94 & 1.14 \\
\hline Seed length & & & & No QTL detected & & & & \\
\hline Seed width & & & & No QTL detected & & & & \\
\hline Seed color & $q S d c 1.1$ & 1 & 662.34 & 73327_179-73327_66 & 19.65 & 70.60 & 0.78 & 0.87 \\
\hline
\end{tabular}



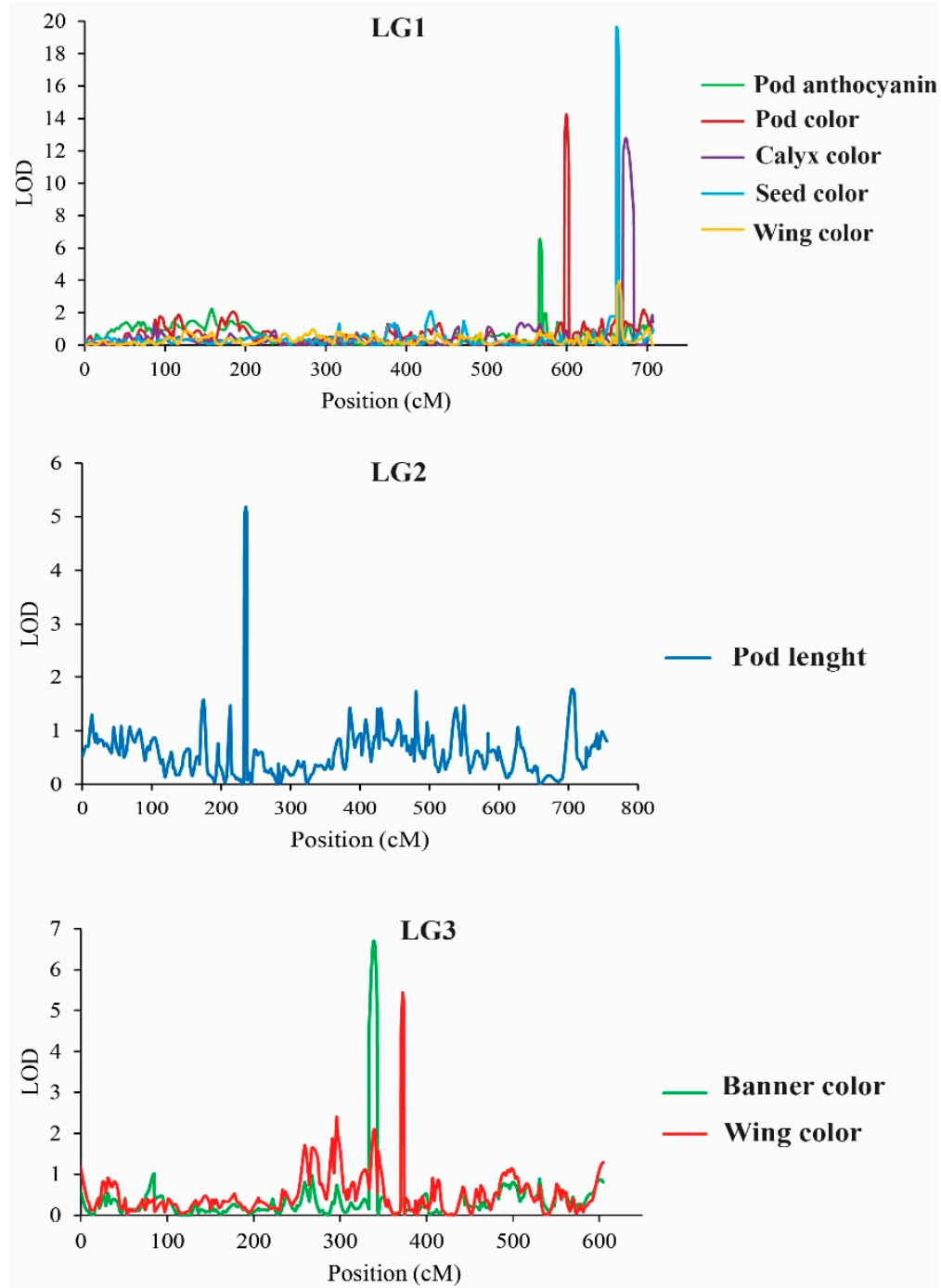

Figure 4. LOD (Logarithm of odds) graphs of quantitative trait loci for flower-, pod-, and seed-related traits detected on LG1, LG2 and LG3 by multiple QTL mapping (MQM) method in the winged bean $\mathrm{F}_{2}$ population developed from the cross W054 $\times$ TPT9. The $x$-axis indicates the linkage groups, whereas the $y$-axis indicates the logarithm of odds (LOD) scores. The dash line horizontal to the $y$-axis indicates the LOD significance threshold.

\subsubsection{QTLs Controlling Organ Coloration}

Two QTLs, qAntho1.1 and $q$ Antho5.1, locating on LGs 1 and 5, were identified for pod anthocyanin content. These QTLs accounted for $28.92 \%$ and $11.61 \%$ of the anthocyanin content variation in the $\mathrm{F}_{2}$ population, respectively. At the $q$ Antho1.1 the allele(s) from W054 increased anthocyanin content, whereas at the qAntho5.1 the allele(s) from TPT9 decreased the anthocyanin content.

Three QTLs located on LGs 1 and 7 were detected for pod color. They explained 9.67\% to $49.15 \%$ of pod color intensity variation in the $\mathrm{F}_{2}$ population. The QTL on LG1, $q P d c 1.1$, showed the largest effect was on the LG1. At all QTLs, allele(s) from W054 increased coloration of the pod. The $q P d c 1.2$ expressed an overdominant gene effect.

Similar to the pod color, three QTLs localizing on LGs1 and 7 were identified for calyx color. These QTLs explained $12.67 \%$ to $38.28 \%$ of calyx color variation in the $\mathrm{F}_{2}$ population. The QTL $q C l x c 1.1$ located on LG1 showed the largest effect towards the calyx color. At these loci, allele(s) from W054 increased coloration of the pod. The $q \mathrm{Cl} x \mathrm{c} 1.2$ showed a very strong overdominant gene effect. 
Five QTLs residing on LGs 1, 3, and 7 were detected for wing color. They accounted for $7.76 \%$ to $18.61 \%$ of the wing color variation in the in the $\mathrm{F}_{2}$ population. Among these QTLs, $q$ Wingc3.1 residing on LG3 showed the largest effect. However, the $q$ Wingc7.1 mapped on LG7 showed comparable effect with the qWingc3.1. Allele(s) from W054 at the qWingc1.1 and $q$ Wingc7.2 increased coloration of the wing. In contrast, allele(s) from W054 at the $q$ Wingc1.2, qWingc3.1 and $q$ Wingc7.1 reduced coloration of the wing. The $q$ Wingc1.2 showed a very strong overdominant gene effect.

Seven QTLs located on LGs 1, 3, 4, 5 and 7 were identified for banner color. They explained $5.53 \%$ to $17.75 \%$ of the banner color variation in the in the $\mathrm{F}_{2}$ population. The QTL on LG3, qBannerc3.1, showed the greatest effect towards the banner color, followed by the qBannerc3.2 that was mapped only $5.0 \mathrm{cM}$ away from the $q$ Bannerc3.1. Allele(s) from W054 at the W054 at the qBannerc1.2, qBannerc1.2, qBannerc3.2 and qBannerc7.1 enhanced coloration of the banner. Allele(s) from W054 at the qBannerc3.1, qBannerc4.1, and qBannerc5.1 reduced coloration of the banner. The qBannerc3.2, qBannerc4.1 and qBannerc5.1 expressed a strong overdominant gene effect, especially the qBannerc3.2.

One major and one minor QTL were identified for seed coat color. The major QTL, $q S d c 1.1$, was localized on LG1, while the minor QTL, $q S d c 3.1$, was located on LG3. They explained $73.34 \%$ and $5.45 \%$ of the seed coat variation in the $\mathrm{F}_{2}$ population, respectively. Allele(s) from W054 at the $q S d c 1.1$ increased intensity of the seed coat color, whereas allele(s) from W054 at the $q S d c 3.1$ decreased the color intensity. The $q S d c 1.1$ expressed an overdominant gene effect.

\subsubsection{QTLs Controlling Organ Size}

Four QTLs for pod length were detected on LGs 1, 2, and 8. These QTLs accounted for $9.449 \%$ to $16.17 \%$ of the pod length variation in the $F_{2}$ population. Among the four QTLs, $q P d l 2.1$ showed the greatest effect. At all these QTLs, allele(s) from W054 enhanced the length. However, all of the QTLs except $q P d l 8.1$ expressed overdominant gene effect.

Only one QTL was detected for seed length, qSdl7.1. This QTL was located on LG7 and explained $18.83 \%$ of the variation of seed length in the $F_{2}$ population. Four QTLs on LGs 1 and 2 were detected for seed width, of which three QTLs were on the LG1. The QTLs explained $11.47 \%$ to $18.52 \%$ of the variation of seed width in the $\mathrm{F}_{2}$ population. The $q S d w 2.1$ on LG02 showed the highest effect. In contrast to other QTLs, at the $q S d w 2.1$ allele(s) from W054 decreased width of the seed. In addition, the $q S d w 2.1$ expressed a very strong overdominant gene effect.

\section{Discussion}

\subsection{Genetics Controlling Traits in Winged Bean}

There are only a few reports on inheritance of traits in winged bean. The winged bean parents, W054 and TPT9, used in this study were strikingly different in several traits related to flower, pod, and seed. Pod anthocyanin content, pod length, seed width, and seed length were considered as quantitative traits, while pod color, calyx color, wing color, banner color, and seed color were considered qualitative traits. Interestingly, these qualitative showed high variation in the $\mathrm{F}_{2}$ mapping population (Figure 2). Some $\mathrm{F}_{2}$ individuals showed color variants that did not present in their parents, particularly flower color (wings and banner) (Figure 2D,E). Transgressive segregation of these traits suggested that coloration in those organs is controlled by more than one gene and that W054 and TPT9 each possess different genetic loci contributing to coloration in those organs. A previous study demonstrated that pod wing color is controlled by a single gene in which purple is dominant to green [29]. In contrast, our study showed that green pod wing is dominant to purple pod wing (Figure 5A). Unfortunately, we did not investigate pod wing color in our $\mathrm{F}_{2}$ population. Additional study is necessary to clarify the contrasted findings between the two studies. 

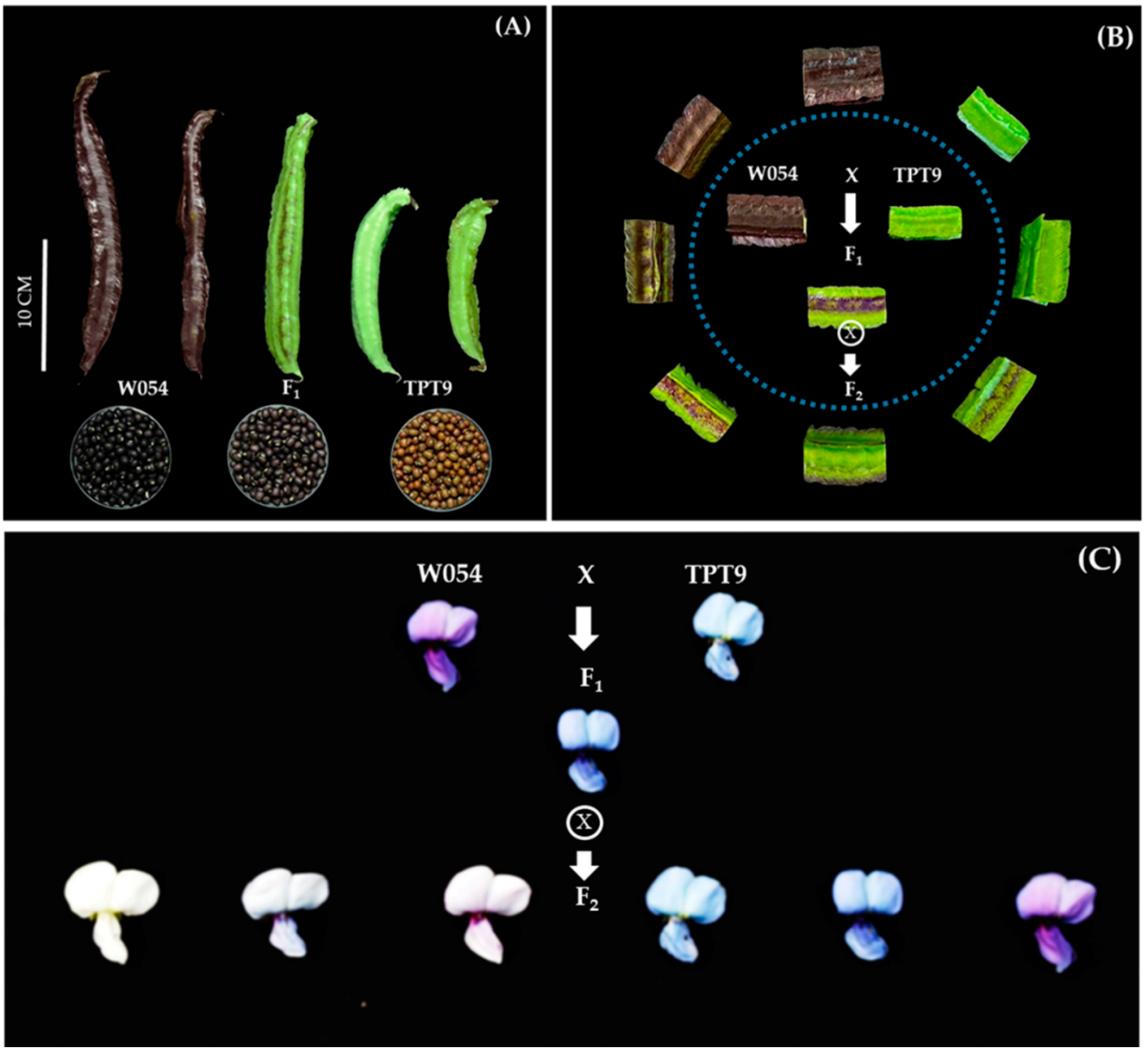

Figure 5. The phenotypes, parental and progenies, of the W054 $\times$ TPT 9 cross. The pods and seeds of W054, TPT9, and $\mathrm{F}_{1}$ progeny are shown in (A), the pod colors of W054, TPT9, $\mathrm{F}_{1}$ progeny, and diversity of eight types are located in the surrounding $\mathrm{F}_{2}$ population $(\mathbf{B})$, and the wing and banner colors of W054, TPT9, $\mathrm{F}_{1}$ progeny, and six types of $\mathrm{F}_{2}$ population are shown in $(\mathbf{C})$.

In this study, correlation analysis of the flower-, pod-, and seed-related traits in the $\mathrm{F}_{2}$ population was determined (Table 1). Moderate to high and significant correlations were found between coloration of these traits (Table 1). These results suggest that these traits are controlled by pleiotropic locus/loci or linked loci. It has been reported that genes controlling stem color and calyx color, and pod wing color and pod speck color are linked [30].

\subsection{The Winged Bean Genetic Linkage Map}

A genetic linkage map is indispensable for QTL analysis and gene discovery for marker-assisted breeding. The SNP-based linkage map constructed for the $\mathrm{F}_{2}$ population in this study is the first genetic map of the winged bean. The map comprised 1384 SNP markers that were assigned to 9 linkage groups corresponding to haploid chromosomes of the winged bean. The total length of the map was $4552.8 \mathrm{cM}$ with average distance between markers of $3.38 \mathrm{cM}$ which is sufficient for genome-wide QTL analysis for economically important traits [31]. In this study, RAD-seq was used to discover SNP markers. RAD-seq has been used for large-scale SNP discovery and genetic mapping in many crop species, especially in species without a reference genome [32-34]. The high-density linkage map constructed for winged bean with the SNPs discovered from RAD-seq indicated that this genotyping method can be applied to develop large-scale SNP markers, and construct high-density molecular genetic maps for winged beans without availability of reference 
genome. The method greatly shortens the sequencing cycle, and reduces the cost of marker development for non-model species [35].

\subsection{QTL Analysis for Flower-, Pod-, and Seed-Related Traits of the Winged Bean}

In this study, QTL analysis using two methods, ICIM and MQM, in the $\mathrm{F}_{2}$ population revealed 31 QTLs in total for nine flower-, pod-, and seed-related traits (Tables 3 and 4). The number per QTL ranged from one (seed length) to seven (banner color). Most of the traits investigated for the QTLs were associated with coloration of organs. The QTLs for organ colorations were clustered on LGs 1,3 and 7 in which some QTLs were mapped to the same or nearly the same position (Tables 3 and 4): for example, $q$ Antho1.1 for pod anthocyanin contents, $q P d c 1.1$ for pod color and $q C l x c 1.1$ for calyx color (Table 3) and $q$ Wingc1.1 for wing color and $q S d c 1.1$ for seed color (Table 4). However, on each LG, different QTLs were also found for the same trait (Table 3). These results suggested that organ coloration in the winged bean is controlled by several QTLs in which some of the traits are likely to be controlled by the same gene(s) (pleiotropic locus) and/or by the linked genes. This is in line with the significant and positive correlation among organ coloration traits in the $\mathrm{F}_{2}$ population (Table 1). The results also suggested that anthocyanin is the major cause of purple pod color and purple calyx color in winged bean.

Among organ coloration traits in the winged bean, the color of young pods is associated with consumer and farmer preferences [10]. In Thailand, most of winged bean cultivars produce green pods, while cultivars with purple pods are rare, especially the ones with dark purple pods [10]. Purple coloration in plants is principally caused by anthocyanin pigments which are associated with health benefits to humans [36,37]. Recently, winged cultivars with purple coloration have become more popular among consumers because of health effects of anthocyanins. In this study, QTL analysis showed that anthocyanin contents in the young pods is controlled by only two major QTLs, qAntho1.1 and qAntho5.1 (Table 3 ). This suggests that breeding new winged bean cultivars with purple young pods may not be difficult. However, interestingly, additive effects towards pod color of the W054 (the parent with dark purple pods) at the qAntho1.1 and qAntho5.1 showed different directions; increasing anthocyanin content at $q$ Antho1.1, while decreasing anthocyanin content at $q A n t h o 5.1$. This may complicate the selection for dark purple pods. The parents, W054 and TPT9, were different in flower color: purple vs. light blue. However, the $\mathrm{F}_{2}$ populations showed wide variants in flower colors (Figure 5C). As many as 12 QTLs were detected for flower color, 5 for wing color and 7 for banner color. Two co-localizations of QTLs were found for wing and banner colors; one on LG1 ( $q$ Wingc1.1 and qBannerc1.1) and one on LG7 (qWingc7.1 and qBannerc7.1) (Table 3). Both purple and blue colors in plants are due to presence of anthocyanin pigments [36,37]. Cyanidin, delphinidin, pelargonidin, peonidin, malvidin, and petunidin are the most common anthocyanidins distributed in the plants [36]. While most of these anthocyanidins give rise to purple or red colors in plants and foods, malvidin and delphinidin provide blue-colored flowers $[38,39]$. The QTLs identified for flower color in the winged bean may be associated with production of different anthocyanidins.

Apart from pod color, pod length is also associated with consumer's and farmer's preferences [10]. Although long and extralong pods are possibly advantageous for pod weight yield and some local consumers and farmers like winged bean cultivars with long and extralong pods, cultivars with short pods are much more popular because of convenience in packaging. In fact, cultivars having extralong pods are scarce [10]. In this study, pod length of the mapping parents W054 and TPT9 were about $10 \mathrm{~cm}$ in difference and four QTLs were identified for this trait. Interestingly, the major QTL qPdl1.1 controlling pod length was mapped to nearly the same position with the major QTL qAntho1.1 conferring pod anthocyanin content (Table 3). This suggests that increasing pod length would not hamper purple pod coloration. Nonetheless, fine mapping is necessary to elucidate the co-localization of the $q P d l 1.1$ and $q$ Antho1.1. It is note-worthy that the $q P d 2.1$, the largest effect QTL for pod length, expressed a strong over-dominance gene 
effect (potence ratio is about 4.1; Table 3). Although this strong overdominance effect may be useful for deployment of hybrid cultivars of winged bean, it can delay development of pure line cultivars in the winged bean as this crop is self-pollinating. Nonetheless, since overdominant effect can stem from allelic interaction or closely-linked genes [40], additional study is necessary to determine the cause of strong overdominance of the qPdl1.1. Moreover, a large population of recombinant inbred lines should be used for confirmation or fine mapping of the QTLs detected in this study.

\section{Materials and Methods}

\subsection{Plant Materials}

An $\mathrm{F}_{2}$ mapping population was developed from a cross between TPT9 and W054. TPT9, an accession originally from Nigeria, has a short green pod, whereas W054 is a commercial winged bean cultivar from the Nakhon Pathom province, Thailand, containing a long purple pod (Figure 5). TPT9 is used as the male parent, crossed onto W054 to develop $F_{1}$ hybrids. An $F_{1}$ hybrid was self-pollinated to produce $F_{2}$ seeds. Eighty-six $F_{2}$ individuals were grown under a field condition for DNA extraction and phenotypic evaluation.

\subsection{Field Evaluation}

The $F_{2}$ mapping population and the parents were sown in a row with $1 \mathrm{~m}$ intra-hole spacing and $1 \mathrm{~m}$ inter-row spacing. The row consisted of 50 plants (W054 and TPT9) which were subjected to a randomized complete block design (RCBD) with non-replication. The experimental field was located at the Agronomy Field Crops Station, Khon Kaen University, Khon Kaen, Thailand, and used from August 2020 to April 2021.

Measurement of pod length: pod length was determined in the $F_{2}$ individuals. Three to five fresh pods were harvested from individual $\mathrm{F}_{2}$ plant at 15 days after flowering (DAF) for pod length $(\mathrm{cm})$ measurement.

Flower-related traits: three flowers of the $\mathrm{F}_{2}$ individuals were observed for banner, wing, and calyx colors using color scoring following IPGRI [41] with a slight modification as white, white blue, white purple, blue, violet, and purple (Figure 5C).

Seed-related traits: ten seeds of the $\mathrm{F}_{2}$ individuals were observed for color using color scoring following IPGRI [41]. Seed length and seed width $(\mathrm{cm})$ were also recorded.

Measurement of pod pigmentation: pigmentation of the $\mathrm{F}_{2}$ pods was recorded using color scoring following IPGRI [41] with a slight modification as green, green with purple spots, green with a purple spot at center, purple wing, purple center, light purple, purple, and dark purple (Figure 5B), and the pod anthocyanin contents were quantified. The sample preparation and extraction of anthocyanin followed a slightly modified method as previously reported [42]. The $\mathrm{pH}$ differential method was used to measure total anthocyanin content (TAC) [43]. Briefly, three fresh pods of each individual $F_{2}$ plant were sliced $(0.2 \mathrm{~g})$ and submerged in $10 \mathrm{~mL}$ of $0.1 \%$ trifluoroacetic acid (TFA) and $95 \%$ ethanol in a $50 \mathrm{~mL}$ tube for anthocyanin extraction. The components were incubated at $4{ }^{\circ} \mathrm{C}$ for six hours until the solution was colorless. The extract was filtrated through qualitative cellulose filter paper (Whatman No.1, Sigma-Aldrich ${ }^{\circledR}$, St. Louis, MO, USA). The anthocyanin of the filtrate was evaluated by UV-Vis spectrophotometer at $530 \mathrm{~nm}$ [42]. The total anthocyanin content was calculated by the following formula:

$$
\mathrm{TAcy}=\mathrm{OD} \times \mathrm{DV} \frac{100 \times \mathrm{TEV}}{\mathrm{SV} \times \mathrm{SW} \times\left(\frac{\mathrm{Ecf}}{10}\right)}
$$

where,

TAcy $=$ total anthocyanin $(\mathrm{mg} / 100 \mathrm{~g})$

$\mathrm{OD}=$ Absorbance $530 \mathrm{~nm}$

$\mathrm{DV}=$ Volume of diluted solution $(\mathrm{mL})$

$\mathrm{SV}=$ Volume of extracted solution for diluted $(\mathrm{mL})$

$\mathrm{TEV}=$ Total extracted volume $(\mathrm{mL})$ 
SW $=$ Sample weight $(\mathrm{g})$

Ecf $=$ Extinction coefficient (Ecf of cyaniding-3-glucoside is 449.2)

\subsection{RAD-Seq}

Total genomic DNA of the parents and $\mathrm{F}_{2}$ population was extracted from fresh leaf tissue using the CTAB method described by Lodhi et al. [44]. The DNA quantity and quality were determined by gel electrophoresis and spectrophotometric measurements. Total genomic DNA (300 ng) was used to construct a RAD-seq [28] library following the protocol in the MGIEasy RAD library preparation kit (MGI Tech). Paired-end (150 bp) sequencing was performed on the MGISEQ-2000RS (MGI Tech) according to the manufacturer's instructions. SNPs were called using Stacks ver. 2.58 [45] and filtered with the following criteria: (a) a minor allele frequency $>0.1$, (b) depth coverage between $10 \times-200 \times$, and (c) fewer than $10 \%$ missing data. In addition, markers showing significant segregation distortion $\left(\chi^{2}\right.$ test $p$-value $\left.<0.01\right)$ and having same genotypes as large haplotype blocks were excluded from further analysis. The filtered SNP markers were used to construct linkage maps.

\subsection{Linkage Map Construction}

A linkage map was constructed utilizing QTL IciMapping 4.2 [46]. The segregation ratio of each SNP marker was determined by chi-square test. Markers showing significant $(p<0.05)$ segregation distortion were excluded from linkage analysis. Then, markers were grouped using log of odds (LOD) value of 7.0. Markers on the same linkage were ordered by recombination counting and ordering (RECORD) algorithm [47] with 2-optMAP function [48]. Map distances were calculated using the Kosambi mapping function [49].

\subsection{QTL Analysis}

QTLs for flower-, pod-, and seed-related traits were identified by inclusive composite interval mapping (ICIM) method [50] implemented in QTL IciMapping 4.1 software [46]. ICIM is performed at every $0.1 \mathrm{cM}$ with a probability in stepwise regression (PIN) of 0.001 . LOD threshold of 3.0 was used to declare the presence of QTLs for each trait. In addition, the QTLs for all the traits were also identified by multi-QTL model (MQM) method using MapQTL 5.0 software [51]. A 1000 permutation test was used to determine the LOD score significance thresholds at a 95\% confidence level.

\section{Conclusions}

In this study, we constructed the first genetic linkage map of the winged bean using SNP markers generated from next generation sequencing technology. We performed QTL mapping for flower color, pod color and length, and seed color and seed size for this crop. The mapping developed in this study is moderately saturated with distance between markers of about $3.0 \mathrm{cM}$ and resolved haploid chromosome number of the winged bean. Several QTLs related to the traits mentioned above were mapped on to the linkage map of which some QTLs were co-localized. This linkage map is useful for molecular breeding studies of the winged bean, while QTLs identified in this study provide better understanding of the genetics of organ coloration in the winged bean.

Supplementary Materials: The following are available online at https:/ / www.mdpi.com/article/ 10.3390/plants11040500/s1, Table S1: SNP information of TPT9, W054, and $\mathrm{F}_{2}$ mapping population. Figure S1: A genetic linkage map of the winged bean [Psophocarpus tetragonolobus (L.) DC.] constructed from an $86 \mathrm{~F}_{2}$ population, derived from the W054 x TPT9 cross, using SNP markers. 


\begin{abstract}
Author Contributions: Conceptualization, S.C. and P.S.; methodology, S.C., S.S., T.R., S.T., W.K., C.S., W.P., K.A. and A.K.; software, S.T., W.K., C.S., W.P., P.S. and K.L.; validation, T.M., S.C., A.K. and J.S.; formal analysis, S.C., S.T., P.S. and A.K.; investigation, S.C.; resources, P.S., T.M. and J.S.; data curation, S.C.; writing —original draft preparation, S.C.; writing—review and editing, S.C. and P.S.; visualization, A.K. and P.S.; supervision, P.S.; project administration, S.C.; funding acquisition, S.C. All authors have read and agreed to the published version of the manuscript.
\end{abstract}

Funding: This research was supported by the Thailand Research Fund (TRF) and Office of the Higher Education Commission (OHEC) (Project code: MGR6280195) and Khon Kaen University.

Institutional Review Board Statement: Not applicable.

Informed Consent Statement: Not applicable.

Data Availability Statement: Data presented in this study are available on request from the corresponding author.

Acknowledgments: This research is financially supported by the Thailand Research Fund (TRF) and Office of the Higher Education Commission (OHEC) (Project code: MGR6280195) and Khon Kaen University. Our gratitude is also extended to the Plant Breeding Research Center for Sustainable Agriculture, Khon Kaen University, Khon Kaen, Thailand.

Conflicts of Interest: The authors declare no conflict of interest.

\title{
References
}

1. Harder, D.K. Chromosome Counts in Psophocarpus. Kew Bull. 1992, 47, 529-534. [CrossRef]

2. Peyachoknagul, S.; Matsui, T.; Shibata, H.; Hara, S.; Ikenaka, T.; Okada, Y.; Ohno, T. Sequence and expression of the mRNA encoding the chymotrypsin inhibitor in winged bean (Psophocarpus tetragonolobus (L.) DC.). Plant Mol. Biol. 1989, $12,51-58$. [CrossRef] [PubMed]

3. Wilson, E. The Diversity of Life; The Belknap Press of Harvard University Press: Cambridge, UK, 1992.

4. Khan, T.N. Papua New Guinea: A centre of genetic diversity in winged bean (Psophocarpus tetragonologus (L.) Dc.). Euphytica 1976, 25, 693-705. [CrossRef]

5. Mohanty, C.S.; Verma, S.; Singh, V.; Khan, S.; Gaur, P.; Gupta, P.; Nizar, M.A.; Dikshit, N.; Pattanayak, R.; Shukla, A.; et al. Characterization of winged bean (Psophocarpus tetragonolobus (L.) DC.) based on molecular, chemical and physiological parameters. Am. J. Mol. Biol. 2013, 3, 187-197. [CrossRef]

6. Adegboyega, T.T.; Abberton, M.T.; Abdelgadir, A.A.H.; Dianda, M.; Maziya-Dixon, B.; Oyatomi, O.A.; Ofodile, S.; Babalola, O.O. Nutrient and Antinutrient Composition of Winged Bean (Psophocarpus tetragonolobus (L.) DC.) Seeds and Tubers. J. Food Qual. 2019, 2019, 3075208. [CrossRef]

7. NAS. The Winged Bean: High-Protein Crop for the Humid Tropics, 2nd ed.; National Academy Press: Washington, DC, USA, 1981; p. 41.

8. Chen, D.; Yi, X.; Yang, H.; Zhou, H.; Yu, Y.; Tian, Y.; Lu, X. Genetic diversity evaluation of winged bean (Psophocarpus tetragonolobus (L.) DC.) using inter-simple sequence repeat (ISSR). Genet. Resour. Crop Evol. 2015, 62, 823-828. [CrossRef]

9. Yang, S.; Grall, A.; Chapman, M.A. Origin and diversification of winged bean (Psophocarpus tetragonolobus (L.) DC.), a multipurpose underutilized legume. Am. J. Bot. 2018, 105, 888-897. [CrossRef]

10. Laosatit, K.; Amkul, K.; Chankaew, S.; Somta, P. Molecular Genetic Diversity of Winged Bean Gene Pool in Thailand Assessed by SSR Markers. Hortic. Plant J. 2021, 8, 81-88. [CrossRef]

11. Vatanparast, M.; Shetty, P.; Chopra, R.; Doyle, J.J.; Sathyanarayana, N.; Egan, A.N. Transcriptome sequencing and marker development in winged bean (Psophocarpus tetragonolobus; Leguminosae). Sci. Rep. 2016, 6, 29070. [CrossRef]

12. Wong, Q.N.; Tanzi, A.S.; Ho, W.K.; Malla, S.; Blythe, M.; Karunaratne, A.; Massawe, F.; Mayes, S. Development of Gene-Based SSR Markers in Winged Bean (Psophocarpus tetragonolobus (L.) DC.) for Diversity Assessment. Genes 2017, 8, 100. [CrossRef]

13. Sriwichai, S.; Monkham, T.; Sanitchon, J.; Jogloy, S.; Chankaew, S. Dual-Purpose of the Winged Bean (Psophocarpus tetragonolobus (L.) DC.), the Neglected Tropical Legume, Based on Pod and Tuber Yields. Plants 2021, 10, 1746. [CrossRef] [PubMed]

14. Eagleton, G. Review: Winged bean (Psophocarpus tetragonolobus) cropping systems. Biodiversitas J. Biol. Divers. 2020, 21, 5927-5946. [CrossRef]

15. Mahto, C.S.; Dua, R.P. Genetic Divergence for Yield Contributing Traits in Winged Bean. Indian J. Plant Genet. Resour. 2009, 22, 239-242.

16. Peterson, B.K.; Weber, J.N.; Kay, E.H.; Fisher, H.S.; Hoekstra, H.E. Double Digest RADseq: An Inexpensive Method for De Novo SNP Discovery and Genotyping in Model and Non-Model Species. PLoS ONE 2012, 7, e37135. [CrossRef] [PubMed]

17. Kang, Y.J.; Kim, S.K.; Kim, M.Y.; Lestari, P.; Kim, K.H.; Ha, B.-K.; Jun, T.H.; Hwang, W.J.; Lee, T.; Lee, J.; et al. Genome sequence of mungbean and insights into evolution within Vigna species. Nat. Commun. 2014, 5, 5443. [CrossRef] [PubMed] 
18. Lonardi, S.; Muñoz-Amatriaín, M.; Liang, Q.; Shu, S.; Wanamaker, S.I.; Lo, S.; Tanskanen, J.; Schulman, A.H.; Zhu, T.; Luo, M.-C.; et al. The genome of cowpea (Vigna unguiculata [L.] Walp.). Plant J. 2019, 98, 767-782. [CrossRef]

19. Singh, A.K.; Velmurugan, A.; Gupta, D.S.; Kumar, J.; Kesari, R.; Konda, A.; Singh, N.P.; Roy, S.D.; Biswas, U.; Kumar, R.R.; et al. Draft genome sequence of a less-known wild Vigna: Beach pea (V. marina cv. ANBp-14-03). Crop J. 2019, 7, 660-666. [CrossRef]

20. Sakai, H.; Naito, K.; Takahashi, Y.; Sato, T.; Yamamoto, T.; Muto, I.; Itoh, T.; Tomooka, N. The Vigna Genome Server, 'VigGS': A genomic knowledge base of the genus Vigna based on high-quality, annotated genome sequence of the azuki bean, Vigna angularis (Willd) Ohwi and Ohashi. Plant Cell Physiol. 2016, 57, e2. [CrossRef]

21. Kreplak, J.; Madoui, M.-A.; Cápal, P.; Novák, P.; Labadie, K.; Aubert, G.; Bayer, P.E.; Gali, K.K.; Syme, R.A.; Main, D.; et al. A reference genome for pea provides insight into legume genome evolution. Nat. Genet. 2019, 51, 1411-1422. [CrossRef]

22. Varshney, R.K.; Chen, W.; Li, Y.; Bharti, A.K.; Saxena, R.K.; Schlueter, J.A.; Donoghue, M.T.; Azam, S.; Fan, G.; Whaley, A.M.; et al. Draft genome sequence of pigeonpea (Cajanus cajan), an orphan legume crop of resource-poor farmers. Nat. Biotechnol. 2012, 30, 83-89. [CrossRef]

23. Varshney, R.K.; Song, C.; Saxena, R.K.; Azam, S.; Yu, S.; Sharpe, A.G.; Cannon, S.; Baek, J.; Rosen, B.D.; Tar'An, B.; et al. Draft genome sequence of chickpea (Cicer arietinum) provides a resource for trait improvement. Nat. Biotechnol. 2013, 31, 240-246. [CrossRef] [PubMed]

24. Lu, Q.; Li, H.; Hong, Y.; Zhang, G.; Wen, S.; Li, X.; Zhou, G.; Li, S.; Liu, H.; Liu, H.; et al. Genome Sequencing and Analysis of the Peanut B-Genome Progenitor (Arachis ipaensis). Front. Plant Sci. 2018, 9, 604. [CrossRef] [PubMed]

25. Kajiya-Kanegae, H.; Nagasaki, H.; Kaga, A.; Hirano, K.; Ogiso-Tanaka, E.; Matsuoka, M.; Ishimori, M.; Ishimoto, M.; Hashiguchi, M.; Tanaka, H.; et al. Whole-genome sequence diversity and association analysis of 198 soybean accessions in mini-core collections. DNA Res. 2021, 28, dsaa032. [CrossRef] [PubMed]

26. Hyten, D.L.; Cannon, S.B.; Song, Q.; Weeks, N.; Fickus, E.W.; Shoemaker, R.C.; Specht, J.E.; Farmer, A.D.; May, G.D.; Cregan, P.B High-throughput SNP discovery through deep resequencing of a reduced representation library to anchor and orient scaffolds in the soybean whole genome sequence. BMC Genom. 2010, 11, 38. [CrossRef]

27. Parchman, T.L.; Gompert, Z.; Mudge, J.; Schilkey, F.D.; Benkman, C.W.; Buerkle, C.A. Genome-wide association genetics of an adaptive trait in lodgepole pine. Mol. Ecol. 2012, 21, 2991-3005. [CrossRef]

28. Baird, N.A.; Etter, P.D.; Atwood, T.S.; Currey, M.C.; Shiver, A.L.; Lewis, Z.A.; Selker, E.U.; Cresko, W.A.; Johnson, E.A. Rapid SNP Discovery and Genetic Mapping Using Sequenced RAD Markers. PLoS ONE 2008, 3, e3376. [CrossRef]

29. Erskine, W.; Khan, T.N. Inheritance of pigmentation and pod shape in winged bean. Euphytica 1977, 26, 829-831. [CrossRef]

30. Freyre, R.; Uzdevenes, C.; Gu, L.; Quesenberry, K.H. Genetics and Anthocyanin Analysis of Flower Color in Mexican Petunia. J. Am. Soc. Hortic. Sci. 2015, 140, 45-49. [CrossRef]

31. Dekkers, J.C.M.; Hospital, F. The use of molecular genetics in the improvement of agricultural populations. Nat. Rev. Genet. 2002, 3, 22-32. [CrossRef]

32. Miller, M.R.; Dunham, J.P.; Amores, A.; Cresko, W.A.; Johnson, E.A. Rapid and cost-effective polymorphism identification and genotyping using restriction site associated DNA (RAD) markers. Genome Res. 2006, 17, 240-248. [CrossRef]

33. Hegarty, M.; Yadav, R.; Lee, M.; Armstead, I.; Sanderson, R.; Scollan, N.; Powell, W.; Skøt, L. Genotyping by RAD sequencing enables mapping of fatty acid composition traits in perennial ryegrass (Lolium perenne (L.)). Plant Biotechnol. J. 2013, 11, 572-581. [CrossRef] [PubMed]

34. Pootakham, W.; Ruang-Areerate, P.; Jomchai, N.; Sonthirod, C.; Sangsrakru, D.; Yoocha, T.; Theerawattanasuk, K.; Nirapathpongporn, K.; Romruensukharom, P.; Tragoonrung, S.; et al. Construction of a high-density integrated genetic linkage map of rubber tree (Hevea brasiliensis) using genotyping-by-sequencing (GBS). Front. Plant Sci. 2015, 6, 367. [CrossRef] [PubMed]

35. Zhao, Y.; Zhao, Y.; Guo, Y.; Su, K.; Shi, X.; Liu, D.; Zhang, J. High-density genetic linkage-map construction of hawthorn and QTL mapping for important fruit traits. PLoS ONE 2020, 15, e0229020. [CrossRef] [PubMed]

36. Khoo, H.E.; Azlan, A.; Tang, S.T.; Lim, S.M. Anthocyanidins and anthocyanins: Colored pigments as food, pharmaceutical ingredients, and the potential health benefits. Food Nutr. Res. 2017, 61, 1361779. [CrossRef] [PubMed]

37. Wallace, T.C.; Giusti, M.M. Anthocyanins-Nature's Bold, Beautiful, and Health-Promoting Colors. Foods 2019, 8, 550. [CrossRef]

38. Tanaka, Y.; Tsuda, S.; Kusumi, T. Metabolic Engineering to Modify Flower Color. Plant Cell Physiol. 1998, 39, 1119-1126. [CrossRef]

39. Katsumoto, Y.; Fukuchi-Mizutani, M.; Fukui, Y.; Brugliera, F.; Holton, T.; Karan, M.; Nakamura, N.; Yonekura-Sakakibara, K.; Togami, J.; Pigeaire, A.; et al. Engineering of the Rose Flavonoid Biosynthetic Pathway Successfully Generated Blue-Hued Flowers Accumulating Delphinidin. Plant Cell Physiol. 2007, 48, 1589-1600. [CrossRef]

40. Crow, J.F.; Crow, J.F. Dominance and Overdominance. In The Genetics and Exploitation of Heterosis in Crops; Coors, J.G., Pandey, S., Eds.; The American Society of Agronomy, Inc.: Madison, WI, USA; Crop Science Society of America, Inc.: Madison, WI, USA, 1999; pp. 49-58. [CrossRef]

41. IBPGR. International Board for Plant Genetic Resources. Revised Winged Bean Descriptors; IBPGR: Rome, Italy, 1982; 24p.

42. Ryu, S.N.; Park, S.Z.; Kang, S.S.; Han, S.J. Determination of C3G content in black purple rice using HPLC and UV-Vis spectrophotometer. Korean J. Crop. Sci. 2003, 48, 369-371.

43. Guisti, M.M.; Wrolstad, R.E. Characterization and Measurement of Anthocyanins by UV-Visible Spectroscopy. Current Protocols in Food Analytical Chemistry; John Wiley and Sons: Hoboken, NJ, USA, 2001; pp. F1.2.1-F1.2.13.

44. Lodhi, M.A.; Ye, G.-N.; Weeden, N.F.; Reisch, B.I. A simple and efficient method for DNA extraction from grapevine cultivars andVitis species. Plant Mol. Biol. Rep. 1994, 12, 6-13. [CrossRef] 
45. Catchen, J.M.; Amores, A.; Hohenlohe, P.; Cresko, W.; Postlethwait, J.H. Stacks: Building and Genotyping Loci De Novo From Short-Read Sequences. G3 Genes Genomes Genet. 2011, 1, 171-182. [CrossRef]

46. Meng, L.; Li, H.; Zhang, L.; Wang, J. QTL IciMapping: Integrated software for genetic linkage map construction and quantitative trait locus mapping in biparental populations. Crop. J. 2015, 3, 269-283. [CrossRef]

47. Van Os, H.; Stam, P.; Visser, R.G.F.; Van Eck, H.J. RECORD: A novel method for ordering loci on a genetic linkage map. Theor. Appl. Genet. 2005, 112, 30-40. [CrossRef] [PubMed]

48. Zhang, L.; Li, H.; Meng, L.; Wang, J. Ordering of high-density markers by the k-Optimal algorithm for the traveling-salesman problem. Crop. J. 2020, 8, 701-712. [CrossRef]

49. Kosambi, D.D. The Estimation of Map Distances From Recombination Values. Ann. Eugen. 1943, 12, 172-175. [CrossRef]

50. Li, H.; Ribaut, J.-M.; Li, Z.; Wang, J. Inclusive composite interval mapping (ICIM) for digenic epistasis of quantitative traits in biparental populations. Theor. Appl. Genet. 2007, 116, 243-260. [CrossRef] [PubMed]

51. Van Ooijen, J. MAPQTL5.0, Software for the Mapping of Quantitative Trait Loci in Experimental Population; Kyazma, B.V., Ed.; Plant Research International: Wageningen, The Netherlands, 2004. 